\title{
Air TRITIA transport model
}

\author{
Marek Drličiak ${ }^{1, *}$, and Ján Čelko ${ }^{1}$ \\ ${ }^{1}$ University of Žilina, Faculty of Civil Engineering, Department of Highway Engineering, Univerzitná \\ 8215/1, SK-010 26 Žilina, Slovak Republic
}

\begin{abstract}
The project AIRTRITIA has a uniform approach to the air pollution management system for functional urban areas in Tritia region. AIR TRITIA aims to increase air quality management capacities of public sector bodies through the development of a unified spatial information database, introducing new management and pollution prediction tools and air quality strategies. The article presents the transport model of Tritia region. The University of Žilina merged data from several traffic models to one on Tritia region. The traffic model will be the main input for the generalized emission model. The main topic of the article is a description of merging of the transport models. The detailed description is aimed to Žilina function area (FUA) in Slovakia.
\end{abstract}

\section{Introduction}

The road transport create one of the main part of the air pollutant emissions. The transport modelling has established a process for many transport project all over the world. The fourstep model (FSM) is the primary tool for forecasting demand and performance of a transportation system. The trip generation, trip distribution, and modal split are three steps, which are calculated gradually or jointly. The calculated origin-destination matrices are used in final step - assignment.

The main of the article is a description of merging of the transport models on Tritia region. The detailed description is aimed to transport model of Žilina town in Slovakia.

\section{TRITIA region}

TRITIA is a 'European Grouping of Territorial Cooperation' in which three regions of Poland, Slovakia and Czech Republic cooperate. Five function areas - FUAs (Ostrava, Opava, Žilina, Opole, Rybnik) and regions of three countries (The Žilina self-governing region, The Moravian-Silesian Region, Silesian Voivodeship, Opole Voivodeship) covered the project area.

\footnotetext{
* Corresponding author: marek.drliciak@,fstav.uniza.sk
} 

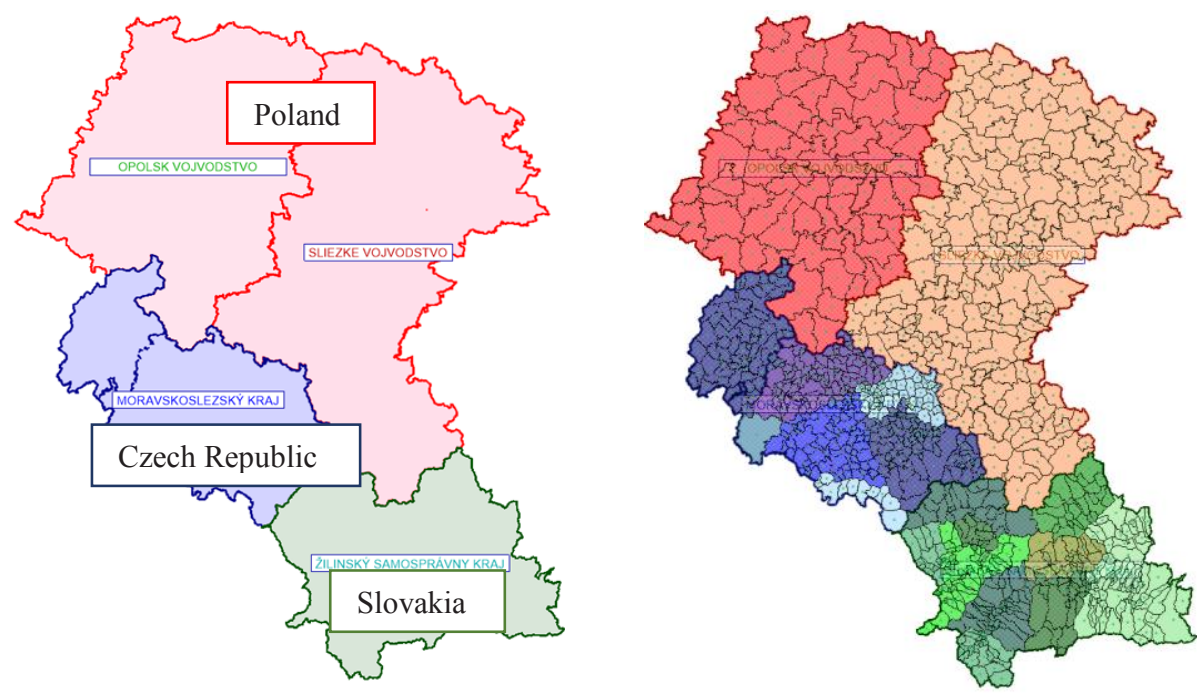

Fig. 1. Tritia region (region- left, zones - right).

\subsection{The Žilina self-governing region}

The Žilina self-governing region is the place with the highest density of protected territories in Slovakia (55,8 \%). The region shares 9 borderline checkpoints with the Czech Republic and Poland. Žilina also plays an important part in the railway transport industry with direct rail links through Čadca and Zwardon to Poland, and from the Czech Republic through Čadca and Žilina to Bratislava or Kosice. Important parts of the international road network lead though Žilina's region, the most important are: E 50 Czech Republic - Žilina - Košice - Ukraine, E 75 Poland - Čadca - Žilina - Hungary and Austria, E 78 Poland - Trstená Dolný Kubín - Šahy - Hungary, E 442 Czech Republic - Makov - Bytča - connected with E 50 and $\mathrm{E} 75$.

The Žilina city is a city in north-western Slovakia, around 200 kilometres from the capital Bratislava. It is the fourth largest city of Slovakia with a population of approximately 82,000, an important industrial centre, the largest city on the Váh river, and the seat of a Žilina Region and a Žilina District.
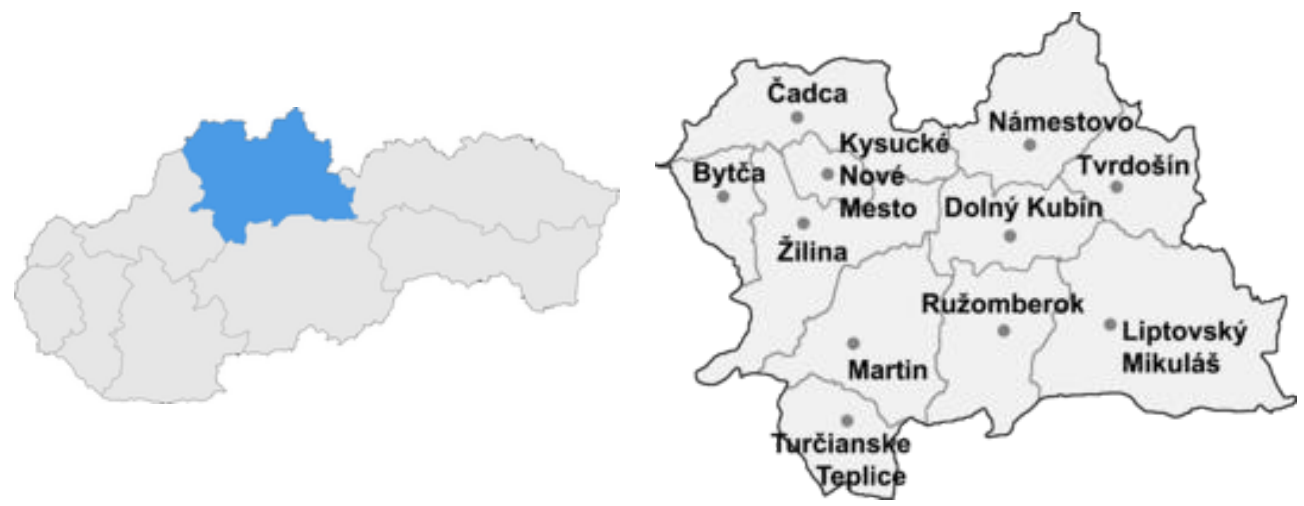

Fig. 2. The Žilina self-governing region. 


\subsection{The Moravian-Silesian Region}

The Moravian-Silesian Region is one of the 14 administrative Regions of the Czech Republic. It borders two countries - Poland (Opole and Silesian Voivodeships) to the north and Slovakia (Žilina Region) to the east.

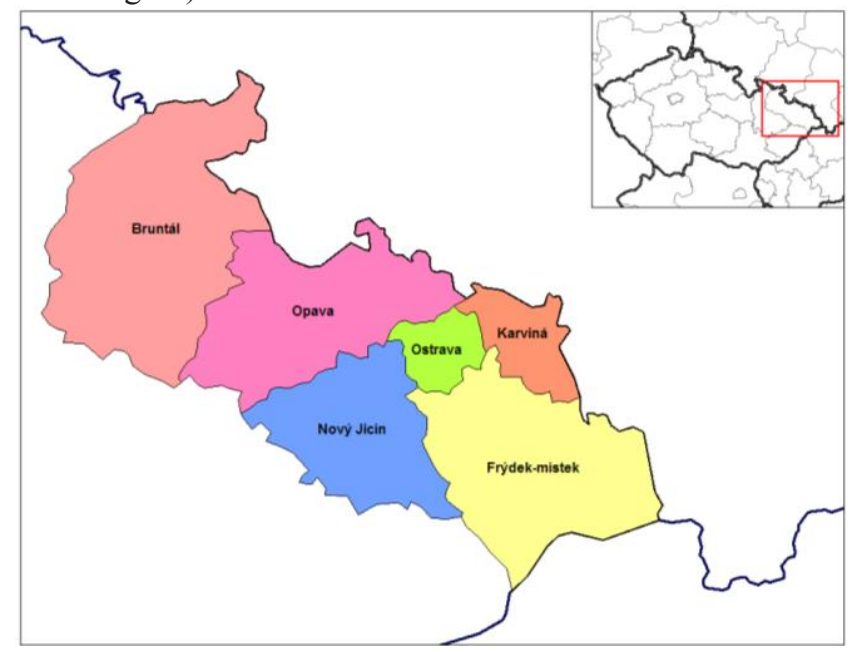

Fig. 3. The Moravian-Silesian Region

Ostrava, the metropolis of Moravian-Silesian region, is by its area and its overall population the third largest city of the Czech Republic. It has a strategic location-it is located 10 kilometers south of the border with Poland and 50 kilometers west of the border with Slovakia. Ostrava is located $360 \mathrm{~km}$ from the capital city of Prague, $170 \mathrm{~km}$ from Brno, $90 \mathrm{~km}$ from the Polish city of Katowice, $310 \mathrm{~km}$ from Vienna. Rivers Odra, Ostravice, Opava, and Lučina flow through the city.

The district town of Opava (with a population of 64,000) is situated on the River Opava, c. $260 \mathrm{~m}$ above sea level. It is an important industrial and cultural center for Czech Silesia and its importance extends beyond district borders.

\subsection{Silesian Voivodeship}

Silesian Voivodeship, or Silesia Province is a voivodeship, or province, in southern Poland, centered on the historic region known as Upper Silesia (Górny Śląsk), with Katowice serving as its capital.

It is the most densely populated voivodeship in Poland and within the area of 12,300 square kilometers, there are almost 5 million inhabitants.[2]. It is also the largest urbanized area in Central and Eastern Europe.[3] In relation to the economy, over 13\% of Poland's Gross Domestic Product (GDP) is generated here, making the Silesian Voivodeship one of the wealthiest provinces in the country. [3][4][5]

The voivodship capital enjoys good railway and road connections with Gdańsk (motorway A1) and Ostrava (motorway A1), Kraków (motorway A4), Wrocław (motorway A4), Łódź (motorway A1) and Warsaw. It is also the crossing point for many international routes like E40 connecting Calais, Brussels, Cologne, Dresden, Wrocław, Kraków, Kiev, and E75 from Scandinavia to the Balkans.

The city of Rybnik is the center of a metropolitan area, the Rybnik Coal Region (Rybnicki Okręg Węglowy) with a total population of 600,000. The distance to Katowice is about $50 \mathrm{~km}(31 \mathrm{mi})$ and to Ostrava about $30 \mathrm{~km}(19 \mathrm{mi})$. 
The city itself has 141,410 inhabitants out of which $88.9 \%$ identified themselves as Polish in the 2002 National Census. Its density is 955.3 per km². The city's population peaked in 1997 at 144,943. After that, it decreased slightly to 141,080 in 2007. Since then, the number of inhabitants has ticked up slightly. Rybnik's demographic situation remains far better than most other Polish cities, with a rather young population: $18.2 \%$ being under the age of 18 and only $15.9 \%$ older than 65 .
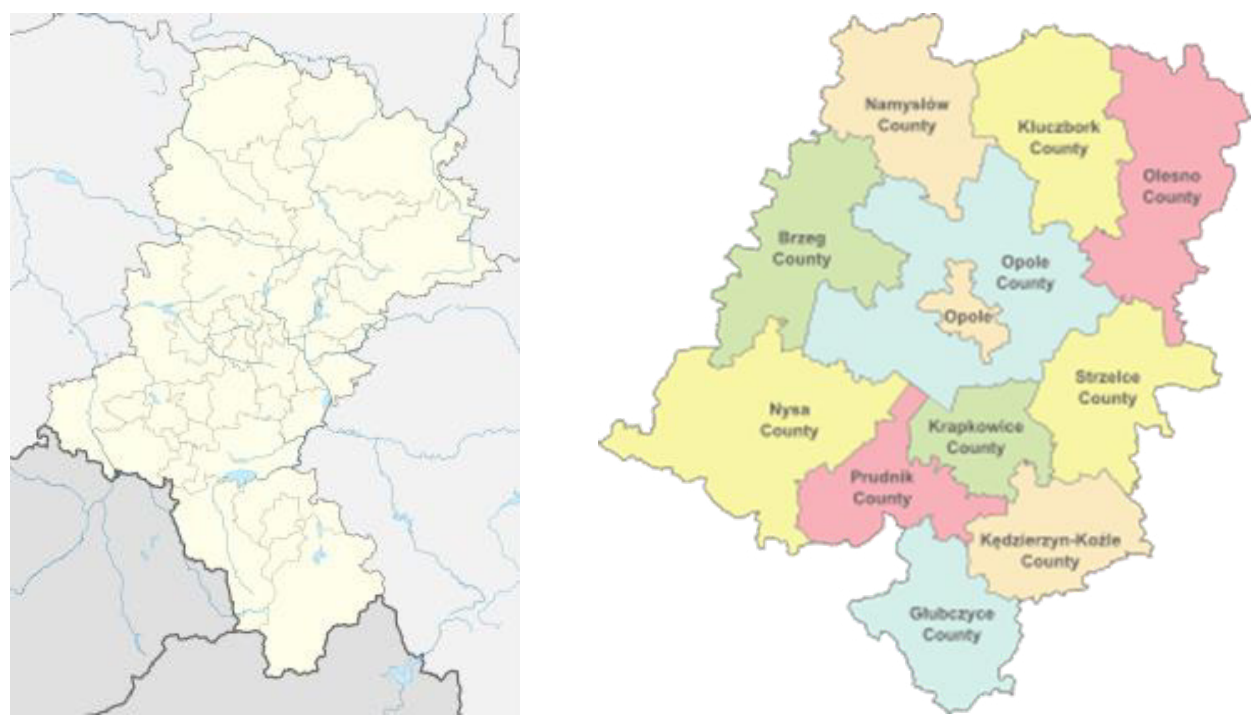

Fig. 4. The Voivodeships in Polland (Opole - left, Silesian - right)

\subsection{Opole Voivodeship}

Opole Voivodeship, or Opole Province [2] is the smallest and least populated voivodeship (province) of Poland. The province's name derives from that of the region's capital and largest city, Opole. It is part of Upper Silesia. A relatively large German minority lives in the voivodeship, with representatives in the Sejm.

The transport route from Germany to Ukraine, the A4, runs through Opole. The region has four border crossings, and direct rail connections to all important Polish cities, as well as to Frankfurt, Munich, Budapest, Kiev, and the Baltic ports.

Opole is s a city located in southern Poland on the Oder River (Odra). With a population of approximately 127,792 (January 2017), it is the capital of the Opole Voivodeship and the seat of Opole County.

\section{Transport model}

A transport model is a mathematical representation of all or part of a transport system. It is used to evaluate existing conditions and to project future effects and needs. In a network model, each zone is represented with a single point (zone centroid). In it all trips' origins and destinations are located, which produce traffic flows among the zones [6], and physical, demographic and socioeconomic variables useful to define the system of activities [7].

The transport model for the project was processed in the PTV Visum program. The program offers detailed network processing, extensive analysis and presentation functions, GIS interface, and environmental impact analysis software. The transport model of the model area was elaborated separately for the Slovak part, Czech part and Polish part. 
The traffic data (volumes, the structure of traffic flows) are imported from national traffic counts in the Slovak Republic, Czech Republic and Polland in 2006, 2010 and 2015.

The data from national traffic census covered only extramural segments of the road network. The town transport models were imported from their own city models.

A multimodal transport model was created for Ostrava (CZ). The whole territory was divided into 1500 transport zones (including the outer ones). The transport path matrix (demand) for each mode of transport was processed based on demographic data and data on the activity of individual zones. Communication network model offer) includes a complete parameterized communication network, including public transport routes and lines and cycling routes. Models of individual, public and bicycle traffic were calibrated to survey data. The output is the intensity of individual transport broken down into passenger and freight vehicles per day and peak periods, the intensity of mass transit passengers divided by tram, trolleybus, urban, regional and train bus per day and peak periods and intensity of cyclists per day [8].

The Opava city (CZ) has been solved by own transport model within the sustainable mobility plan. The mentioned model was imported to the AirTritia transport model using shp files.

The transport model of the Rybnik (PL) area has been provided for the project AirTritia in the source file (.ver). The data was imported to the modelled area.

The modelling of air quality on AirTritia area must cover areas, which detailed scaled of transport is necessary. The project AirTritia contains Opole and Rybnik cities. Katowice and Częstochowa were added to transport model area due to its transport importance.
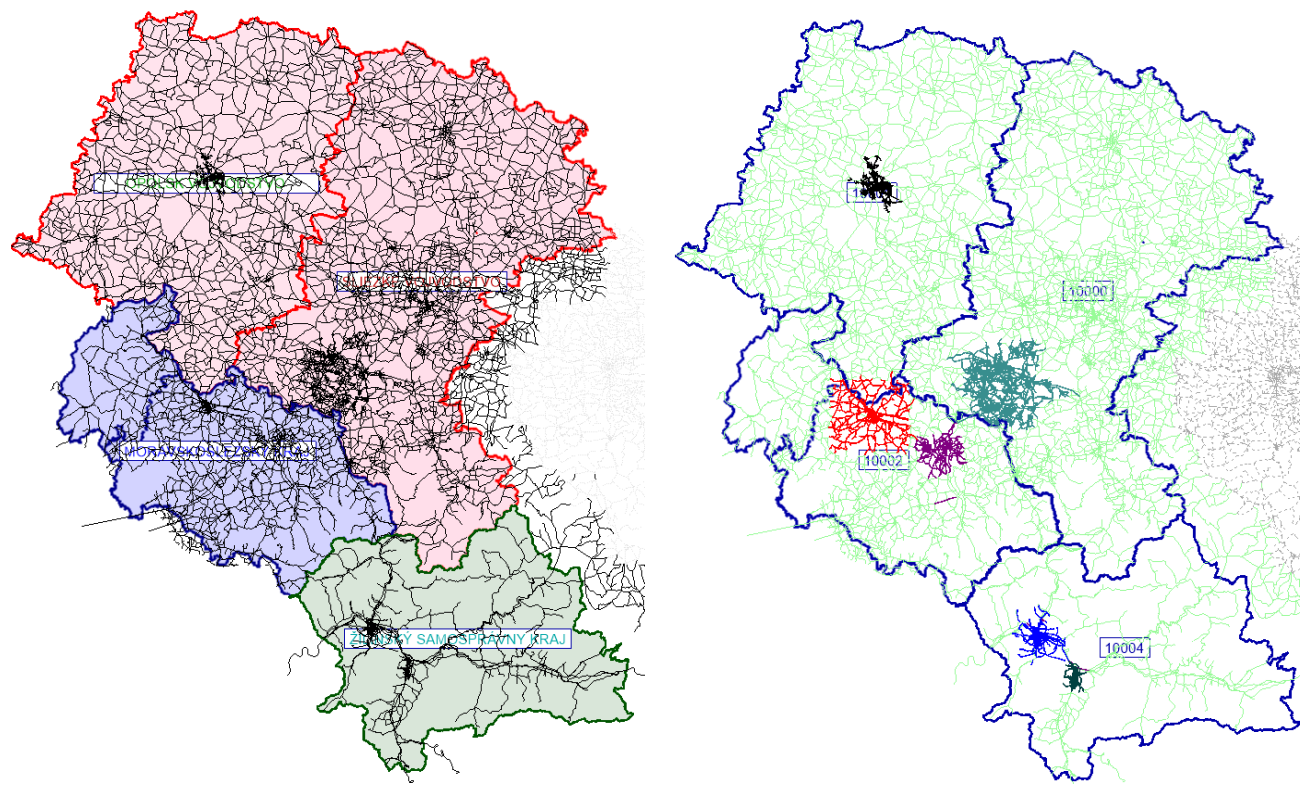

Fig. 5. The supply model (Tritia area - left, FUAs models - right)

\section{Transport model of Žilina}

The Žilina transport model was created on the vector maps (S-JTSK: Geographic Coordinate Systems). The model of the roads network (supply model) was made in parallel with the demand model. The definition of transport zones is the first basic step, which needs time and detailed knowledge about the solved area. The official urban town zoning 
system and the statistical area units were used as a base template for the traffic zoning system. The special areas (shopping centres, university...) were defined as the independent zones. The Žilina model area includes 60 town zones and 58 extra-urban zones.

The calculation of demand transport relations is based on classic four-step model (trips generation, trips distribution, modal split and assignment model). The source data are obtained from the results of the large mobility survey (1800 households). The mobility survey describes transports habits of inhabitants and households.

The inhabitants are divided by the social and traffic impact on the traffic process. The data from transport counts was analysis by the modeled data.

The data obtained from household surveys forms the basis for demand model development. Usually it uses single or multiple regression (linear or nonlinear) formulas to estimate parameters of particular trip modelling procedures, gravity and mode choice models parameters etc. The calibration process of mentioned values requires data from household survey sample, which later, using statistical tools, is weighted [10].

Fig. 6 shows the mutual comparison $\left(\mathrm{R}^{2}=0,98\right)$ of final volumes on selected segments with observed values (actual traffic counts data).

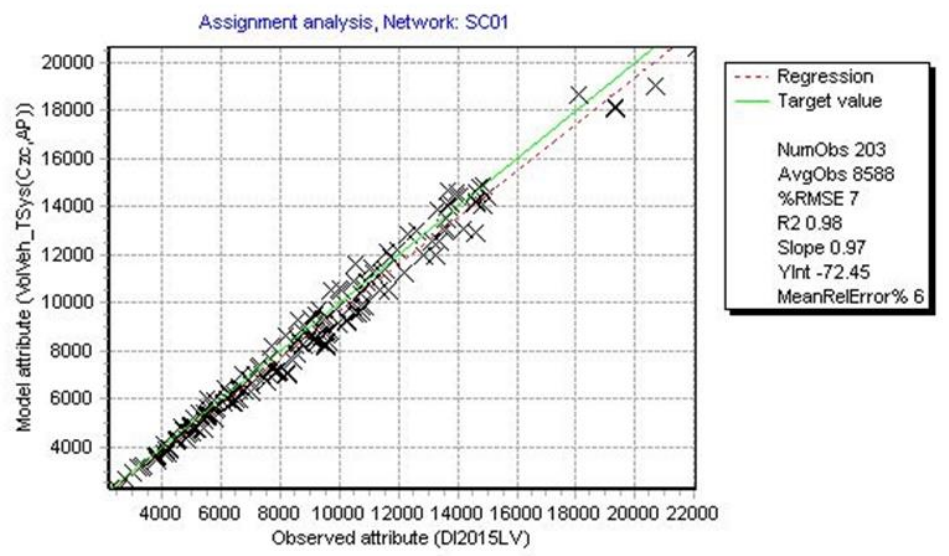

Fig. 6. The assignment analysis of Žilina transport model

\section{Input dada to the generalized emission model}

The final AirTritia model contains 915 zones, 31193 nodes, and 749601 inks. The model was made in PTV Vision, Visum transport software. PTV Visum is the world's leading software for traffic analyses, forecast, and GIS-based data management.[9]

The Air pollution model (the modelling system ADMoSS for detailed modelling of air quality) then processes the exported GIS format of the AirTritia transport model (.shp files). The cities transport models providers allowed the use of final data from models without demand model. The data was used in strategic documents of mention cities.

The traffic data (transport volumes) are divided into the six base user attributes:

- light vehicles:

$\circ$ AT2015L,
$\circ$ AT2010L,
$\circ$ AT2005L,

- heavy vehicles:

AT2015T,

AT2010T,

- AT2005T. 
Data represent daily average traffic volumes (veh/24h) (Fig. 6).

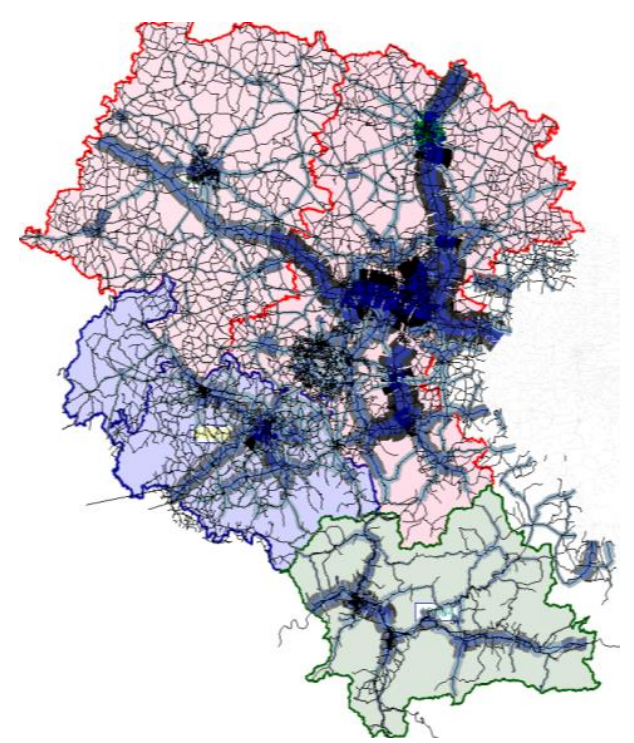

Fig. 7. The final transport model in GIS

\section{Conclusion}

Integrated strategic planning for air quality improvement will be incorporated in both joint regional strategy and respective strategies for FUAs. These strategies will take into account not only local influences but also regional and trans-boundary impacts. Individual strategies for five target FUAs in TRITIA region (Ostrava, Opava, Rybnik, Opole, and Žilina). Each strategy addresses specific problems of Air Quality.

The University of Žilina integrated the data from transport models and traffic counts. The final traffic model will be the main input for the generalized emission model.

The research is supported by the project AIR TRITIA Uniform approach to the air pollution management system for functional urban areas in Tritia region. The project is supported by the Interreg Central Europe Programme funded under the European Regional Development Fund.

\section{Interreg

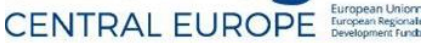

\section{AIR TRITIA}

The paper originated as being supported by means of a grant KEGA 045ŽU-4/2017 Environmental education of engineers for application in public administration

\section{References}

1. The Žilina self-governing region; http://www.regionzilina.sk/en/zilina-selfgoverningregion/regions/ (2018) 
2. Integrovaný plán mobility Ostrava - část IV. - prezentační (http://mobilitaostrava.cz/ke-stazeni/ )

3. Śląskiego, Urząd Marszałkowski Województwa. "Województwo Śląskie - Śląskie. Pozytywna energia" (PDF). www.silesia-europa.pl. (2018)

4. "Śląski Urząd Wojewódzki w Katowicach - strona oficjalna" (2016)

5. "The Śląskie Voivodeship". Archived from the original on 30 June 2016.

6. Mayer M.D., Miller E.J.. Urban transportation planning. A decision oriented approach.Ed. (2001)

7. McGraw Hill McNally M.G..The four step model. Da Handbook of transport modelling (chapter 3).Ed. Hensher D.A. and Button K.J., Pergamon (2000)

8. Ludność. Stan i struktura ludności oraz ruch naturalny w przekroju terytorialnym $\mathrm{w}$ 2017 r. Stanu w dniu 30 VI 2017 r" (in Polish). Warszawa: Główny Urząd Statystyczny. 2017. Archivedfrom the original on 2014-10-15 (2017)

9. PTV Vision (http://vision-traffic.ptvgroup.com/en-us/products/ptv-visum/)

10. T. Kulpa, A. Szarata: Analysis of household survey sample size in the trip modelling process, Proceedings of 6th Transport Research Arena, Warsaw, Poland, (April 18-21, 2016) 